\title{
Optimization of palm oil refining process for reduction of 3- monochloropropane-1,2-diol ester to obtain low MCPD palm oil
}

\author{
Vispute Pratik and Dabhade Surekha
}

Received : 01.06.2018; Revised : 08.08.2018; Accepted : 25.08 .2018

See end of the Paper for authors' affiliation

Correspondence to :

Vispute Pratik Department of Agricultural Engineering, Maharashtra Institute of Technology, Aurangabad (M.S.) India Email : pratikvispute5@ gmail.com

\begin{abstract}
-ABSTRACT : The reduction in level of 3-monochloropropane-1, 2-diol esters in RBD palm oil is accomplished by optimizing the processing steps in the refining process. The main purpose of optimization of palm oil refining process is to get low MCPD palm oil with acceptable quality of refined palm oil. The refining process for palm oil is optimized by modifying four processing parameters: types of bleaching earths, bleaching earth dosage, bleaching temperature and deodorization temperature. For degumming step, temperature of $85^{\circ} \mathrm{C}$ and 0.02 per cent of phosphoric acid was carried out for 1 hour. Two different types of bleaching earths namely neutral bleaching earth and acidic bleaching earth at the dosage of 1 per cent, 2 per cent and 3 per cent were used. The bleaching of degummed oil is performed at different temperatures: $85^{\circ} \mathrm{C}, 90^{\circ} \mathrm{C}, 100^{\circ} \mathrm{C}$, and $110^{\circ} \mathrm{C}$ for 1 hour. Deodorization of bleached oil was performed at $200^{\circ} \mathrm{C}, 220^{\circ} \mathrm{C}$ and $250^{\circ} \mathrm{C}$ for 1 hour. 3-MCPD levels were analyzed by GC/MS. 3-MCPD was not detected in the crude palm oil. Bleaching at $110^{\circ} \mathrm{C}$ temperature with 1 per cent acidic bleaching earth and deodorized at $250^{\circ} \mathrm{C}$ temperature reported to have highest levels (1.99 ppm) of 3-MCPD esters in RBD palm oil. The 3-MCPD esters were at lower levels $(1.33 \mathrm{ppm})$ when the degummed oil is bleached at $90^{\circ} \mathrm{C}$ for 1 hour with 3 per cent neutral bleaching earth and deodorized at $250^{\circ} \mathrm{C}$ for 1 hour. Although study indicates that this optimized refining process also affect the physico-chemical properties of palm oil.
\end{abstract}

- KEY WORDS : 3-MCPD esters, Bleaching, Bleaching earth, Degumming, Deodorization, GC/ MS, RBP palm oil

- HOW TO CITE THIS PAPER : Pratik, Vispute and Surekha, Dabhade (2018). Optimization of palm oil refining process for reduction of 3-monochloropropane-1,2-diol ester to obtain low MCPD palm oil. Internat. J. Agric. Engg., 11(2) : 305-313, DOI: 10.15740/HAS/IJAE/11.2/305-313. Copyright@2018: Hind Agri-Horticultural Society. 